\title{
Influence of sampling gear in assessment of reproductive parameters for bluefin tuna in the western Mediterranean
}

\author{
Antonio Medina ${ }^{1, *}$, Francisco J. Abascal ${ }^{5}$, Lourdes Aragón ${ }^{1}$, Gabriel Mourente ${ }^{1}$, \\ Guillermo Aranda ${ }^{1}$, Txema Galaz ${ }^{2}$, Antonio Belmonte ${ }^{3}$, J. Miguel de la Serna ${ }^{4}$, \\ Salvador García ${ }^{4}$
}

\author{
${ }^{1}$ Departamento de Biología, Facultad de Ciencias del Mar y Ambientales, Avda. República Saharaui, s/n, \\ 11510 Puerto Real, Cádiz, Spain \\ ${ }^{2}$ Ecolofish, Pol. Ind. Los Alcázares, Vial A - Nave 3, Apdo. 186, 30710 Los Alcázares, Murcia, Spain \\ ${ }^{3}$ Tuna Graso, S.A., Carretera de la Palma Km 7, Paraje la Estrella, 30593 Cartagena, Murcia, Spain \\ ${ }^{4}$ Instituto Español de Oceanografía, Puerto pesquero s/n, Apdo. 285, 29640 Fuengirola, Málaga, Spain \\ ${ }^{5}$ Instituto Español de Oceanografía, Unidad de Cádiz, Puerto Pesquero, Muelle de Levante, s/n \\ Apdo. 2609, 11006 Cádiz, Spain
}

\begin{abstract}
Comparative histological and stereological analysis of gonads from longline- and purse seine-caught Atlantic bluefin tuna Thunnus thynnus was undertaken to assess the reproductive potential of the population in the western Mediterranean breeding area. Bluefin tuna sampled by purse seine clearly had higher gonadosomatic index values (GSI) than those caught by longline. While no remarkable histological differences were found between purse seine- and longline-caught males, the ovarian histology indicated a higher level of maturity in females from purse-seine samples, where most specimens were found to be in active spawning (AS). Within the longline sample the proportion of active spawning females was considerably higher at the end of the fishing season (midJune to mid-July) than earlier in May to mid-June (52.8 vs. $24 \%$ ). Stereological analyses revealed that the samples collected by the 2 sampling gears differed primarily in the numbers of migratorynucleus oocytes, which were overwhelmingly more abundant in purse-seine catches, with average relative fecundity: 59 oocytes $\mathrm{g}^{-1}$ vs. 1.2 oocytes $\mathrm{g}^{-1}$ (purse-seine vs. longline). The frequency of ovaries with postovulatory follicles (POFs) in purse seine-caught bluefin tuna was $83.7 \%$, equivalent to a spawning interval of $1.2 \mathrm{~d}_{\text {i }}$ in contrast, only $32.6 \%$ of the females in longline catches had POFs, representing a spawning interval of $3.1 \mathrm{~d}$. Assuming an average individual duration of the spawning process of $14 \mathrm{~d}$, and considering the estimates of fecundity and spawning interval obtained from purse-seine samples, the average annual fecundity of bluefin tuna in the Balearic spawning ground

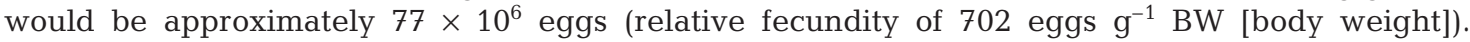

KEY WORDS: Bluefin tuna - Thunnus thynnus - Reproduction · Fecundity · Gonad histology · Stereology

\section{INTRODUCTION}

Modern electronic tagging programs have provided invaluable data on the dynamics of Atlantic bluefin tuna populations (Lutcavage et al. 1999, 2000, Block et al. 2001, 2005, De Metrio et al. 2002, 2003, Wilson et al.
2005), but this information needs to be accompanied with meaningful biological interpretations of migratory patterns. Accurate assessment of reproductive parameters, such as age at maturity, fecundity, spawning frequency, and spawning sites and schedules, is essential for understanding the population dynamics of 
tunas and for the management of tuna fisheries. Considerable progress has been made in recent years in understanding the reproduction of Atlantic bluefin tuna, but many questions still remain to be answered. One of the most controversial issues regarding bluefin tuna reproductive biology is age-at-maturity. While age at $50 \%$ maturity has been definitely established at $3 \mathrm{yr}$ for eastern populations (Corriero et al. 2005), maturity is believed to start as late as Age 6 in the western stock (Baglin 1982). Such a difference in ageat-maturity between eastern and western populations is difficult to support in terms of reproductive physiology and ecology, hence further investigations on bluefin tuna reproduction in the West Atlantic and Mediterranean are needed with a view to clarifying these and other discrepancies. The classical list of Mediterranean spawning sites (Balearic archipelago and southern Thyrrhenian Sea) has recently been extended, with the addition of 2 spawning grounds located in the Levantin Sea (Karakulak et al. 2004, Oray \& Karakulak 2005) and around Malta (A. Corriero pers. comm.). Understanding and quantifying the reproductive potential of local bluefin tuna populations in all these geographic locations is of great importance to research into population dynamics and management models for the species.

A major limitation of biological research on wild bluefin tuna populations is the nearly complete dependence of scientific sampling on commercial fisheries. The inability to design the most appropriate sampling protocols and methods of capture may result in biased interpretations associated with the particular selectivity of the fishing gear used. In the present study, a comparative histological and stereological analysis of gonads from bluefin tuna caught by longline and purse seine vessels was undertaken with the aim to (1) improve our knowledge on the reproductive biology of bluefin tuna in the western Mediterranean breeding area, and (2) evaluate the influence of the methods of capture in the assessment of reproductive parameters.

\section{MATERIALS AND METHODS}

Sample collection. Breeding bluefin tuna were sampled from waters around the Balearic Islands by longline and purse-seine vessels. A total number of 223 ind. - 140 females and 83 males - were collected by Japanese-type longline between May and July in 2003, 2004 and 2005. Their estimated weight averaged $201.5 \pm 52.1 \mathrm{~kg}$ (range: 15 to $375 \mathrm{~kg}$ ). The longlines bore up to 1200 hooks baited with squid Illex spp., which were distributed in the water column at depths ranging between $\sim 50 \mathrm{~m}$ (water temperature $15-17^{\circ} \mathrm{C}$ ) and $125 \mathrm{~m}\left(\sim 14^{\circ} \mathrm{C}\right)$. The lines were always retrieved at dawn, usually 36 to $48 \mathrm{~h}$ after they were set. The purseseine sample was obtained between mid-June and mid-July in 2000, 2001, 2002 and 2005, and comprised a total number of 99 tuna, 56 females and 43 males, weighing $122.8 \pm 83.7 \mathrm{~kg}$ (range: 15 to $349 \mathrm{~kg}$ ). This sample was far smaller than the longline sample because purse seine-caught tuna are maintained alive for farming; therefore only the few specimens that die during fishing operations or transfer to towing cages are available.

All individual tuna were measured to the lowest $1 \mathrm{~cm}$ curved fork length (CFL); this measure was then transformed into straight fork length (FL) using the formula: $\mathrm{FL}=\mathrm{CFL} \times 0.955$. This allowed further estimation of total body weight (BW), according to the equation BW $=1.9607 \times 10^{-5} \times \mathrm{FL}^{3.0092}$ (For ICCAT conversion factors see: http://iccat.es/Documents/Stats/convers.pdf). Following evisceration, the gonad pairs were weighed to the nearest $1 \mathrm{~g}$, and the gonadosomatic index (GSI) calculated as GSI $=\mathrm{GW} \times 100 / \mathrm{BW}$, where GW represents the gonad weight. Volumetry of gonads is frequently difficult to carry out aboard commercial fishing vessels. So when ovarian volume (OV) measures were unavailable, OV was estimated from ovarian weight $(\mathrm{OW})$ using the equation: $\mathrm{OV}=0.9174 \times \mathrm{OW}$, which resulted from a previous regression analysis between OW and OV values measured in a sample of 141 individuals whose OW ranged between 0.54 and $7.29 \mathrm{~kg}\left(\mathrm{r}^{2}=0.98\right)$.

Histology. A transverse slice from the middle region of 1 of the gonads (ca. $5 \mathrm{~mm}$ thick) was cut into smaller pieces, each comprising several lamellae, which were fixed and preserved in $4 \%$ neutral buffered formaldehyde until use. Once in the laboratory, tissue samples were dehydrated in a graded series of ethanol, cleared in xylene and embedded in paraffin wax. The volume loss occurred throughout dehydration of the ovarian tissue in 28 specimens was estimated to be close to $25 \%$, with $V_{\mathrm{F}}=0.72 \times V_{\mathrm{I}}\left(\mathrm{r}^{2}=\right.$ $0.89 ; \mathrm{n}=28$ ), where $V_{\mathrm{F}}$ is the volume of the histological specimen measured after dehydration and $V_{\mathrm{I}}$ represents its initial volume.

Cross histological sections were cut at $6 \mu \mathrm{m}$ and testicular samples stained with haematoxylin-eosin (H-E), whereas ovarian sections were stained with haematoxylin-VOF (H-VOF) (Gutiérrez 1967). H-VOF staining was preferred over conventional H-E staining for ovarian tissue because it aids identifying tiny yolk granules in early vitellogenic oocytes, thus allowing neat discrimination between this population of oocytes and large previtellogenic oocytes (lipid stage), which have similar size and morphological appearance. Slides were examined and photographed on a Leitz DMR BE light microscope equipped with a digital camera. 
Male histological classification. Male tuna are considered mature (Fig. 1) when spermatozoa are present in the sperm duct. Schaefer $(1996,1998)$ proposed a further classification for mature males based on histological evidence of recent spawning, which is detectable only within $12 \mathrm{~h}$ following the spawning event. Unfortunately, accurate determination of the spawning condition of males was impracticable in this study because the exact
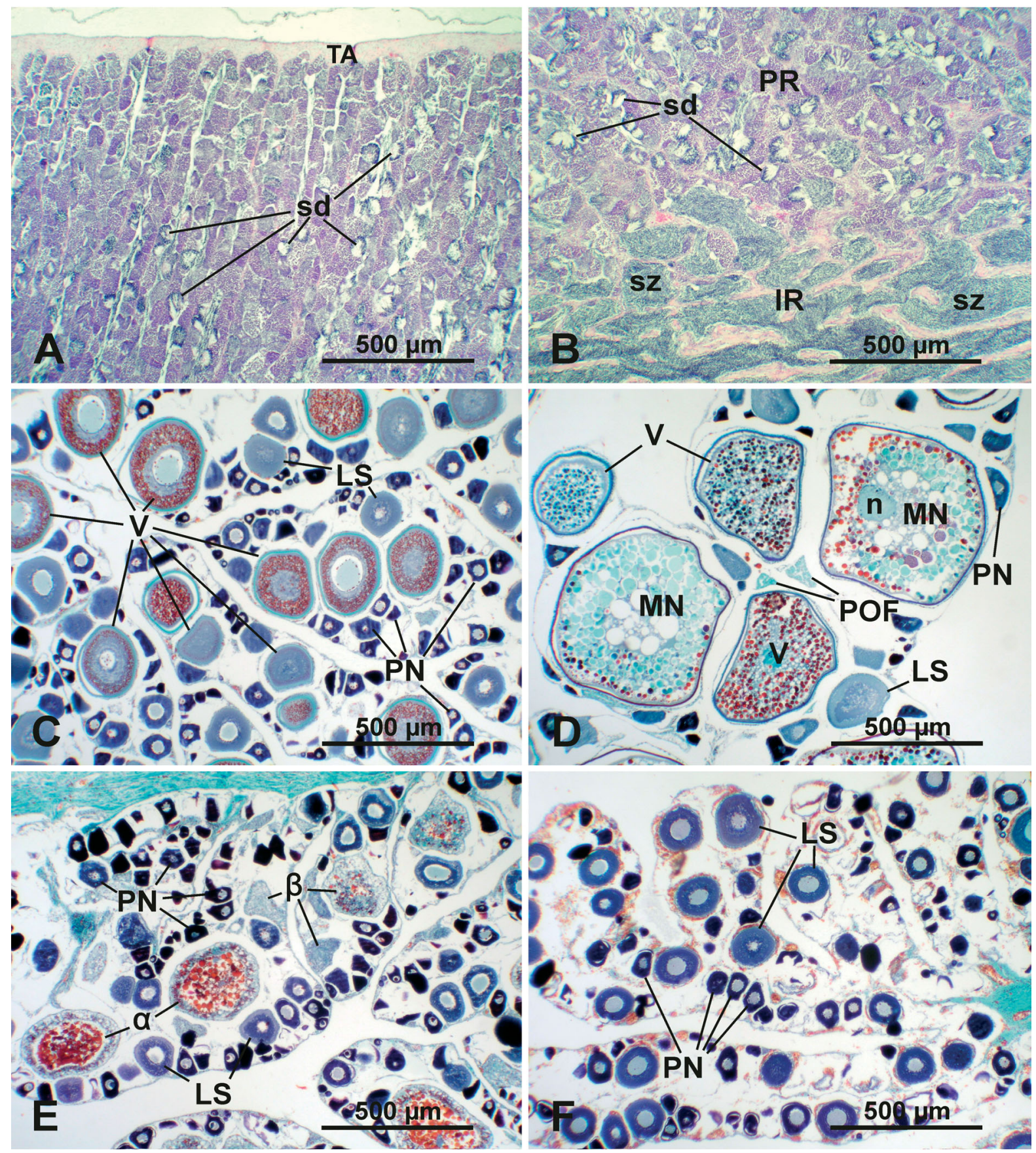

Fig. 1. Thunnus thynnus. Micrographs of transverse sections of bluefin tuna gonads. (A,B) Testes (H-E staining). (A) Peripheral region showing cysts of developing germ cells. (B) Transition between peripheral (PR) and inner (IR) regions. (C-F) Ovaries of (C) active nonspawning, (D) active spawning, (E) inactive mature, and (F) immature tuna (H-VOF staining). LS: lipid-stage oocytes; MN: migratory nucleus oocytes; n: nucleus; PN: perinucleolar oocytes; POF: postovulatory follicles; sd: late spermatid cysts; sz: free spermatozoa; TA: tunica albuginea; V: vitellogenic oocytes; $\alpha$ : $\alpha$ atretic follicles; $\beta$ : $\beta$ atretic follicles 
time of capture was unavailable and some histological specimens did not include the main sperm duct.

Oocyte and female classification. Bluefin tuna show an asynchronous pattern of ovarian development (Baglin 1982, Schaefer 2001, Susca et al. 2001, Corriero et al. 2003, Abascal \& Medina 2005). Hence, all stages of oocyte development can be found in the ovary during the reproductive season. According to the different developmental stages, oocytes were classified as perinucleolar, lipid stage, vitellogenic, migratory nucleus, and hydrated (Fig. 1). Additionally, histological sections of the ovaries were examined for the presence of atretic and postovulatory follicles. Although vitellogenic oocytes are commonly divided into early yolked and advanced yolked (Schaefer 2001), we have grouped all these oocytes into a single class because no clear borderline can be objectively traced between 2 distinct categories of vitellogenic oocytes, which may cause problems in stereological quantifications. Depending on the most advanced group of oocytes encountered in the ovary and the extent of atresia, and following classifications by Schaefer $(1996,1998)$ and Schaefer et al. (2005), female bluefin tuna were classed into one of 4 maturational stages (Fig. 1). The ovaries of active nonspawning (AN) females contain advanced vitellogenic oocytes and minor, if any, $\alpha$ atresia (Fig. 1C). Females are classified as active spawning (AS) if the ovaries show additional evidence of either recent spawning (postovulatory follicles are present) or imminent spawning (migratory-nucleus or hydrated oocytes can be identified) (Fig. 1D). Females are considered inactive mature (IM) when they have entered into regression following a phase of reproductive activity, in which case the ovary contains either previtellogenic or early yolked oocytes plus $\alpha$ and/or $\beta$ atresia (Fig. 1E), or advanced yolked oocytes plus major atresia. Finally, in immature (I) females, only previtellogenic or early yolked oocytes (and no sign of atresia) are found in the ovary (Fig. 1F).

Image analysis and stereology. Ten different images of each ovarian histological section were recorded. A calibration scale was photographed at the same magnification in order to accurately determine cell dimensions in the digital images.

The number of oocytes of different categories present in the ovaries was estimated by the stereological method (Weibel \& Gómez 1962, Weibel et al. 1966), which has been applied for oocyte counting in various fish species (Emerson et al. 1990, Greer Walker et al. 1994, Coward \& Bromage 1998, 2001, 2002a,b, Bromley et al. 2000, Medina et al. 2002, Murua et al. 2003, Cooper et al. 2005). The stereological procedure allows calculation of the number of oocytes per unit volume of ovary ( $N_{V}$, numerical density) from microscope images, according to the formula:

$$
N_{V}=\frac{K}{\beta} \frac{N_{A}^{3 / 2}}{V_{V}^{1 / 2}}
$$

where $\beta$ is a shape coefficient, $K$ is a size distribution coefficient, $N_{A}$ is the number of oocyte transections per unit area, and $V_{V}$ is the partial area of oocytes of a given category (volume fraction or volume density). The total number of oocytes contained in the gonads is then readily obtained extrapolating $N_{V}$ to the whole ovarian volume. We did not count perinucleolar oocytes, since the size of this stock has been found to remain invariable at about 6500 cells per gram of BW throughout the reproductive season (Medina et al. 2002).

The procedure employed for stereological analysis was as described by Medina et al. (2002) with a slight modification. In the previous study $V_{V}$ was calculated according to the original methodology, that is, by counting the number of points of a Weibel grid that overlaid the transections of the considered oocyte type on printed micrographs. In the present investigation we have determined $V_{V}$ by image analysis of digital micrographs using the software 'ImageJ' (See: http://rsb.info.nih.gov/ij/). Both procedures produced equivalent results.

Statistical analysis. Individual sizes were found to be correlated with fecundity, so to test differences between both groups, data of GSI, $V_{V}, N_{V}$, absolute number of oocytes, and relative number of oocytes were compared by analysis of covariance (ANCOVA) with BW as the covariate. Dunn-Sidak multiple comparison tests were performed, when relevant, using SPSS statistical software. A p-value of $<0.05$ was considered statistically significant for all tests.

\section{RESULTS}

\section{Gonadosomatic indices}

Longline-caught male tuna showed significantly smaller gonads $(\mathrm{GSI}=2.87 \pm 1.49)$ than specimens caught by purse-seine (GSI $=4.27 \pm 1.71$ ) (Table 1 ). Different gonad development was also found between females caught by longline (GSI $=2.83 \pm 1.39$ ) and purse-seine (GSI = $3.85 \pm 1.66$ ). We found no interannual significant differences in GSI values within groups of tuna caught with the 2 different gears.

In order to analyse possible temporal differences in longline-caught tuna, the whole sample was split into 2 groups corresponding to early captures carried out in May through mid-June and later catches occurred between mid-June and mid-July. This latter group encompassed longline catches that co-exist temporally with the purse-seine fishery. Multiple comparison test following the ANCOVA analysis showed 
Table 1. Thunnus thynnus. GSI (gonadosomatic index) and stereological data (mean $\pm \mathrm{SD}$ ) from bluefin tuna caught by longline and purse seine. n: number of ind. examined. *Significant differences between the 2 groups of means (ANCOVA, $\mathrm{p}<0.05$ ). $V_{V}$ : volume fraction of oocytes; $N_{V}$ : number of oocytes per unit volume of ovary

\begin{tabular}{|c|c|c|}
\hline & Longline & Purse Seine \\
\hline \multicolumn{3}{|l|}{ Males } \\
\hline GSI & $\begin{array}{c}2.87 \pm 1.49 \\
\mathrm{n}=82\end{array}$ & $\begin{aligned} 4.27 & \pm 1.71^{*} \\
\mathrm{n} & =42\end{aligned}$ \\
\hline \multicolumn{3}{|l|}{ Females } \\
\hline GSI & $\begin{array}{c}2.83 \pm 1.39 \\
\mathrm{n}=138\end{array}$ & $\begin{aligned} 3.85 & \pm 1.66^{*} \\
\mathrm{n} & =56\end{aligned}$ \\
\hline \multicolumn{3}{|c|}{ Lipid-stage oocytes } \\
\hline$V_{V}$ & $\begin{array}{c}0.06 \pm 0.02 \\
\mathrm{n}=119\end{array}$ & $\begin{aligned} 0.07 & \pm 0.04^{*} \\
\mathrm{n} & =49\end{aligned}$ \\
\hline$N V\left(\mathrm{ml}^{-1}\right)\left(\times 10^{3}\right)$ & $\begin{array}{c}31.58 \pm 17.60 \\
\mathrm{n}=119\end{array}$ & $\begin{array}{c}31.47 \pm 22.22 \\
\mathrm{n}=49\end{array}$ \\
\hline No. ind.$^{-1}\left(\times 10^{6}\right)$ & $\begin{array}{c}169.19 \pm 135.04 \\
n=116\end{array}$ & $\begin{array}{c}126.29 \pm 112.11 \\
\mathrm{n}=48\end{array}$ \\
\hline No. $g^{-1} B W\left(g^{-1}\right)$ & $\begin{array}{c}841.79 \pm 602.77 \\
n=116\end{array}$ & $\begin{aligned} 929.51 & \pm 523.28^{*} \\
\mathrm{n} & =48\end{aligned}$ \\
\hline \multicolumn{3}{|c|}{ Vitellogenic oocytes } \\
\hline$V_{V}$ & $\begin{array}{c}0.26 \pm 0.12 \\
\mathrm{n}=119\end{array}$ & $\begin{array}{c}0.24 \pm 0.11 \\
\mathrm{n}=49\end{array}$ \\
\hline$N_{V}\left(\mathrm{ml}^{-1}\right)\left(\times 10^{3}\right)$ & $\begin{array}{c}9.70 \pm 4.07 \\
\mathrm{n}=119\end{array}$ & $\begin{array}{c}7.71 \pm 3.68^{*} \\
\mathrm{n}=49\end{array}$ \\
\hline No. ind. ${ }^{-1}\left(\times 10^{6}\right)$ & $\begin{array}{c}55.26 \pm 33.34 \\
\mathrm{n}=116\end{array}$ & $\begin{array}{c}34.04 \pm 36.04 \\
\mathrm{n}=48\end{array}$ \\
\hline No. $g^{-1}$ BW $\left(g^{-1}\right)$ & $\begin{array}{c}284.60 \pm 160.74 \\
\mathrm{n}=116\end{array}$ & $\begin{array}{c}282.17 \pm 193.62 \\
\mathrm{n}=48\end{array}$ \\
\hline \multicolumn{3}{|c|}{ Final-maturation oocytes } \\
\hline$V_{V}$ & $\begin{array}{c}0.01 \pm 0.03 \\
\mathrm{n}=119\end{array}$ & $\begin{aligned} 0.19 & \pm 0.14^{*} \\
\mathrm{n} & =49\end{aligned}$ \\
\hline$N_{V}\left(\mathrm{ml}^{-1}\right)\left(\times 10^{3}\right)$ & $\begin{array}{c}0.06 \pm 0.23 \\
\mathrm{n}=119\end{array}$ & $\begin{aligned} 2.06 & \pm 2.23^{*} \\
\mathrm{n} & =49\end{aligned}$ \\
\hline No. ind. ${ }^{-1}\left(\times 10^{6}\right)$ & $\begin{array}{c}0.30 \pm 1.22 \\
\mathrm{n}=116\end{array}$ & $\begin{array}{c}9.47 \pm 13.51^{*} \\
\mathrm{n}=48\end{array}$ \\
\hline No. $g^{-1}$ BW $\left(g^{-1}\right)$ & $\begin{array}{c}1.65 \pm 6.50 \\
\mathrm{n}=116\end{array}$ & $\begin{array}{c}81.63 \pm 96.16^{*} \\
\mathrm{n}=48\end{array}$ \\
\hline \multicolumn{3}{|l|}{ Atretic oocytes } \\
\hline$V_{V}$ & $\begin{array}{c}0.07 \pm 0.07 \\
\mathrm{n}=119\end{array}$ & $\begin{aligned} 0.04 & \pm 0.06^{*} \\
\mathrm{n} & =49\end{aligned}$ \\
\hline
\end{tabular}

that GSI remained unchanged throughout the whole fishing campaign in females caught by longline (Table 2). This appears to indicate that dissimilarities in the degree of ovarian development observed between longline and purse-seine samples are largely due to markedly different selectivity of the gears rather than temporal differences. For males, however, strongly different GSI values were found between the specimens caught by longline in May to mid-June and those caught by purse seine, whereas the tuna fished by longline between mid-June and mid-July exhibited intermediate GSI values that were not statistically different from either of the 2 other groups (Table 2).

\section{Histology}

Males

Histological features of testes from all specimens examined suggested the occurrence of active spermatogenesis in both purse-seine- and longline-caught bluefin tuna. At the peripheral region of the testes, the seminiferous lobules show cysts of germ cells at all developmental stages of spermatogenesis (Fig. 1A). The central ducts of the testes lack cysts of developing male gametes, and serve for the storage of spermatozoa (Fig. 1B). There were no marked histological differences indicative of functional differences in testicular activity between longline- and purse-seine-caught tuna. Therefore, the overall histological structure of testes can hardly account for the great disparity found in the GSIs of both groups.

\section{Females}

Unlike males, female tuna sampled by longline and purse seine differed in overall gonad histology, suggesting a distinct state of maturation. The greater part $(96.3 \%)$ of the purse-seine sample (52 out of 54 ind. examined for histology) consisted of AS females, only 1 female was $\mathrm{AN}$ and the remaining females were classified as IM (Fig. 2A). There were no I specimens among the female tuna caught by purse seine. In the longline sample $35.6 \%$ of the females (47 out of 132) were identified as $\mathrm{AS}, 54.6 \%$ were considered $\mathrm{AN}$, $8.3 \%$ IM, and only 2 individuals $(1.5 \%)$ were classified as I (Fig. 2A). These proportions change significantly when the longline sample is divided into 2 fishing periods as indicated above. In the group of females caught during May through mid June, 24.0\% of the individuals were AS and $72.2 \%$ AN, whereas $52.8 \%$ of the females caught between mid June and mid July were AS and 28.3\% AN (Fig. 2A). It is remarkable that the percentage of IM fish was relatively high $(17.0 \%)$ in the sample collected during the second period of the longline fishing season in comparison to earlier catches $(2.5 \%)$. The low proportion of I females remained consistent (ca. 1.5\%) throughout the whole longline fishing season.

Postovulatory follicles were present in $83.7 \%$ of the females caught by purse seine (Fig. 2B). Considering a maximum permanence of POFs in the ovary of $24 \mathrm{~h}$, the average spawning frequency can then be estimated in 0.84 spawns $\mathrm{d}^{-1}$, which corresponds to an average interspawning interval of $1.19 \mathrm{~d}$. If only active tuna are considered, the estimated spawning frequency and spawning interval correspond to $0.85 \mathrm{~d}^{-1}$ and $1.17 \mathrm{~d}$, respectively. 
Table 2. Thunnus thynnus. Comparison between GSI and stereological data (mean $\pm \mathrm{SD}$ ) from longline- and purse-seine-caught bluefin tuna (n: number of ind. examined). When ANCOVA analyses indicated significant differences $(p<$ 0.05), Dunn-Sidak multiple comparison tests were applied. Values in the same row bearing different superscripts were significantly different

\begin{tabular}{|c|c|c|c|}
\hline & \multicolumn{2}{|c|}{$\longrightarrow$ Longline $\longrightarrow$} & \multirow{2}{*}{$\begin{array}{c}\text { Purse Seine } \\
\text { (mid Jun-mid Jul) }\end{array}$} \\
\hline & (May-mid Jun) & (mid Jun-mid Jul) & \\
\hline \multicolumn{4}{|l|}{ Males } \\
\hline GSI & $\begin{array}{c}2.64 \pm 1.30^{\mathrm{a}} \\
(\mathrm{n}=60)\end{array}$ & $\begin{array}{c}3.50 \pm 1.81^{\mathrm{a}, \mathrm{b}} \\
(\mathrm{n}=22)\end{array}$ & $\begin{array}{c}4.34 \pm 1.68^{\mathrm{b}} \\
(\mathrm{n}=42)\end{array}$ \\
\hline \multicolumn{4}{|l|}{ Females } \\
\hline GSI & $\begin{array}{c}2.81 \pm 1.39^{\mathrm{a}} \\
(\mathrm{n}=86)\end{array}$ & $\begin{array}{c}2.86 \pm 1.41^{\mathrm{a}} \\
(\mathrm{n}=52)\end{array}$ & $\begin{array}{c}3.85 \pm 1.66^{\mathrm{b}} \\
(\mathrm{n}=56)\end{array}$ \\
\hline \multicolumn{4}{|c|}{ Lipid-stage oocytes } \\
\hline$V_{V}$ & $\begin{array}{c}0.07 \pm 0.02^{\mathrm{b}} \\
(\mathrm{n}=74)\end{array}$ & $\begin{array}{c}0.05 \pm 0.02^{\mathrm{a}} \\
(\mathrm{n}=45)\end{array}$ & $\begin{aligned} 0.07 & \pm 0.04^{\mathrm{b}} \\
(\mathrm{n} & =49)\end{aligned}$ \\
\hline$N V\left(\mathrm{ml}^{-1}\right)\left(\times 10^{3}\right)$ & $\begin{array}{c}38.18 \pm 17.02^{\mathrm{b}} \\
(\mathrm{n}=74)\end{array}$ & $\begin{array}{c}20.73 \pm 12.52^{\mathrm{a}} \\
(\mathrm{n}=45)\end{array}$ & $\begin{aligned} 31.47 & \pm 22.22^{\mathrm{b}} \\
(\mathrm{n} & =49)\end{aligned}$ \\
\hline No. ind. ${ }^{-1}\left(\times 10^{6}\right)$ & $\begin{aligned} 212.29 & \pm 147.75^{\mathrm{b}} \\
(\mathrm{n} & =72)\end{aligned}$ & $\begin{array}{c}98.68 \pm 67.31^{\mathrm{a}} \\
(\mathrm{n}=44)\end{array}$ & $\begin{array}{c}126.29 \pm 112.11^{\mathrm{b}} \\
(\mathrm{n}=48)\end{array}$ \\
\hline No. $g^{-1}$ BW $\left(g^{-1}\right)$ & $\begin{array}{c}1020.15 \pm 645.76^{b} \\
(n=72)\end{array}$ & $\begin{array}{c}549.93 \pm 377.77^{\mathrm{a}} \\
(\mathrm{n}=44)\end{array}$ & $\begin{array}{c}929.51 \pm 523.28^{b} \\
(\mathrm{n}=48)\end{array}$ \\
\hline \multicolumn{4}{|c|}{ Vitellogenic oocytes } \\
\hline$V_{V}$ & $\begin{array}{c}0.25 \pm 0.10 \\
(\mathrm{n}=74)\end{array}$ & $\begin{array}{l}0.29 \pm 0.13 \\
(\mathrm{n}=45)\end{array}$ & $\begin{array}{l}0.24 \pm 0.11 \\
(\mathrm{n}=49)\end{array}$ \\
\hline$N V\left(\mathrm{ml}^{-1}\right)\left(\times 10^{3}\right)$ & $\begin{array}{c}9.87 \pm 3.65^{\mathrm{b}} \\
(\mathrm{n}=74)\end{array}$ & $\begin{array}{c}9.43 \pm 4.71^{\mathrm{a}, \mathrm{b}} \\
(\mathrm{n}=45)\end{array}$ & $\begin{array}{c}7.71 \pm 3.68^{\mathrm{a}} \\
(\mathrm{n}=49)\end{array}$ \\
\hline No. ind..$^{-1}\left(\times 10^{6}\right)$ & $\begin{array}{c}57.81 \pm 34.62 \\
(\mathrm{n}=72)\end{array}$ & $\begin{array}{c}51.08 \pm 31.05 \\
\quad(\mathrm{n}=44)\end{array}$ & $\begin{array}{c}34.04 \pm 36.04 \\
(\mathrm{n}=48)\end{array}$ \\
\hline No. $g^{-1}$ BW $\left(g^{-1}\right)$ & $\begin{array}{c}284.22 \pm 159.36 \\
(\mathrm{n}=72)\end{array}$ & $\begin{array}{c}285.24 \pm 164.84 \\
\quad(\mathrm{n}=44)\end{array}$ & $\begin{array}{c}282.17 \pm 193.62 \\
(\mathrm{n}=48)\end{array}$ \\
\hline \multicolumn{4}{|c|}{ Final-maturation oocytes } \\
\hline$V_{V}$ & $\begin{array}{c}0.00 \pm 0.00^{\mathrm{a}} \\
(\mathrm{n}=74)\end{array}$ & $\begin{array}{c}0.01 \pm 0.02^{\mathrm{a}} \\
(\mathrm{n}=45)\end{array}$ & $\begin{array}{c}0.19 \pm 0.14^{\mathrm{b}} \\
(\mathrm{n}=49)\end{array}$ \\
\hline$N V\left(\mathrm{ml}^{-1}\right)\left(\times 10^{3}\right)$ & $\begin{array}{c}0.04 \pm 0.21^{\mathrm{a}} \\
(\mathrm{n}=74)\end{array}$ & $\begin{aligned} & 0.09 \pm 0.27^{\mathrm{a}} \\
&(\mathrm{n}=45)\end{aligned}$ & $\begin{aligned} 2.06 & \pm 2.23^{b} \\
(\mathrm{n} & =49)\end{aligned}$ \\
\hline No. ind..$^{-1}\left(\times 10^{6}\right)$ & $\begin{array}{c}0.20 \pm 1.12^{\mathrm{a}} \\
(\mathrm{n}=72)\end{array}$ & $\begin{array}{c}0.45 \pm 1.38^{\mathrm{a}} \\
(\mathrm{n}=44)\end{array}$ & $\begin{array}{c}9.47 \pm 13.51^{\mathrm{b}} \\
(\mathrm{n}=48)\end{array}$ \\
\hline No. $g^{-1} B W\left(g^{-1}\right)$ & $\begin{array}{c}1.01 \pm 5.08^{\mathrm{a}} \\
(\mathrm{n}=72)\end{array}$ & $\begin{array}{c}2.69 \pm 8.28^{\mathrm{a}} \\
(\mathrm{n}=44)\end{array}$ & $\begin{array}{c}81.63 \pm 96.16^{\mathrm{b}} \\
(\mathrm{n}=48)\end{array}$ \\
\hline \multicolumn{4}{|l|}{ Atretic oocytes } \\
\hline$V_{V}$ & $\begin{array}{c}0.06 \pm 0.05^{\mathrm{a}} \\
(\mathrm{n}=74)\end{array}$ & $\begin{aligned} 0.08 & \pm 0.09^{\mathrm{b}} \\
(\mathrm{n} & =45)\end{aligned}$ & $\begin{aligned} 0.04 & \pm 0.06^{\mathrm{a}} \\
(\mathrm{n} & =49)\end{aligned}$ \\
\hline
\end{tabular}

Among all longline-caught fish the specimens containing POFs represented only $32.6 \%$ of the sample, which is equivalent to an average spawning interval of $3.1 \mathrm{~d}$. Marked differences appear to occur depending on the date when the samples were taken. Thus, while POFs occurred in only $22.8 \%$ of the early catches (between early May and mid June), with a spawning interval of $4.4 \mathrm{~d}, 49.0 \%$ of females caught during the second period of the longline season (from mid-June to mid-July) had spawned within the previous $24 \mathrm{~h}$, representing an average interval of $2 \mathrm{~d}$ between consecutive spawns (Fig. 2B). If only active fish caught during this period are considered, the frequency of ovaries containing POFs is $58.1 \%$, which corresponds to a spawning interval of $1.72 \mathrm{~d}$. This spawning frequency is closer to that found in the purse-seine sample, but nevertheless reflects clear differences between the 2 sampling gears, even though both captures were carried out in the same period.

\section{Stereology}

Table 1. summarizes the results of the stereological analysis in longline and purse-seine samples. For lipidstage oocytes, significant differences were found in the values of fractional volume $\left(V_{V}\right)$ and in the estimated number of oocytes per $g$ of BW. In vitellogenic oocytes, a slight but significant difference was present only in the numerical density $\left(N_{V}\right)$, whereas the other parameters showed statistically similar values, especially the relative number of vitellogenic oocytes (number of yolked oocytes per $\mathrm{g}$ of BW). The strongest differences between the 2 samples were encountered in the population of oocytes at final maturation, which includes migratorynucleus and hydrated oocytes. All the estimates $\left(V_{V}, N_{V}\right.$, absolute and relative numbers of oocytes) proved to be statistically different in the 2 groups (Table 1). Particularly in purse seine-caught tuna, the average number of oocytes at final maturation, which may be considered as a reliable proxy of the species' batch fecundity, was ca. 9 million (82 oocytes $\mathrm{g}^{-1}$ ), whereas a rather exiguous amount of 300000 final-maturation oocytes (less than 2 finalmaturation stage oocytes $\mathrm{g}^{-1}$ ) was estimated for the longline sample.

It should be noted that dehydration of tissues prior to histological embedding results in volume losses that would affect such stereological parameters as $N_{V}$ and its numerical derivatives, i.e. absolute and relative number of oocytes. After applying the previously calculated correction factor of 0.72 , the resulting average batch fecundities are 6.5 million eggs (relative fecundity of 59 eggs $\mathrm{g}^{-1}$ ) in purse seine-caught individuals and 216000 eggs $\left(1.2\right.$ eggs g $\left.^{-1}\right)$ in longline-caught individuals. 


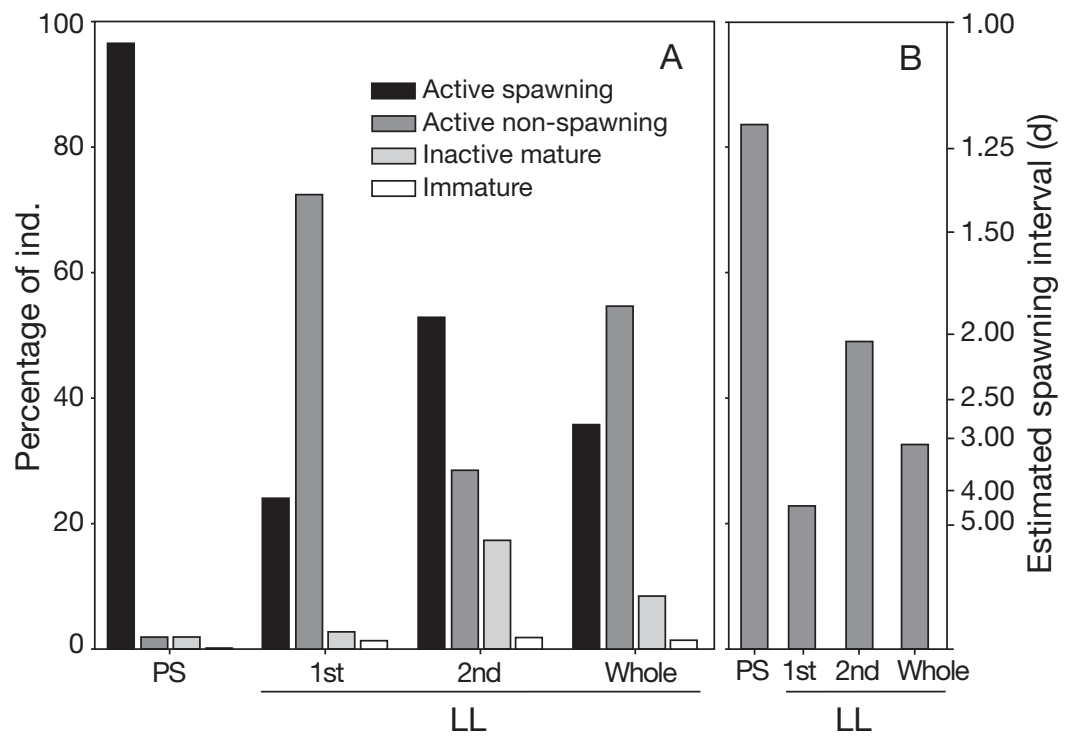

Fig. 2. Thunnus thynnus. Summarized results of histological analysis for females. (A) Percentages of specimens pertaining to the 4 different histological categories for longline and purse-seine samples. (B) Frequencies of females with postovulatory follicles (\%) and the associated estimated spawning intervals (d). For longline sample, 'whole' catch was split into 2 distinct periods: early catches (May through mid-June, 1st); and late catches (mid-June to mid-July, 2nd). LL: longline; PS: purse seine

Considering 2 separate periods for the longline fishery does not modify greatly these results (Table 2). The amount of final-maturation oocytes present in the gonad were not significantly different between early and late longline catches, both values remaining far lower than in the purse-seine sample. In vitellogenic oocytes, differences persisted in $N_{V}$ between early-caught longline tuna and purse-seine tuna, with values in late-caught longline tuna that were intermediate between those of the 2 other groups, whereas all other stereometric parameters proved statistically similar. In particular, the estimated number of vitellogenic oocytes per $\mathrm{g}$ of BW was virtually identical in all 3 groups (Table 2). Interestingly, stereological analysis of lipid-stage oocytes gave similar results in all estimated stereological parameters in earlycaught longline tuna and purse-seine tuna, whereas these values were lower in tuna captured by longline at the end of the fishing season (Table 2).

It appears that the extremely low mean number of final-maturation oocytes estimated for the longline sample in comparison to the tuna captured with purse seine is largely due to the small proportion of fish containing oocytes of this category in the ovaries. Nevertheless, when only specimens having oocytes at final maturation stage are considered in the statistical analysis, differences persist between both groups, with means of about 95 migratory-nucleus oocytes $\mathrm{g}^{-1}$ in purse seine-caught tuna vs. 21 migratory-nucleus oocytes $\mathrm{g}^{-1}$ in longlinecaught tuna.

\section{DISCUSSION}

In the Mediterranean Sea, bluefin tuna are caught mainly by purse seine and longline fleets. It is thought that these gears target fish that display behavioural differences and are probably at different reproductive conditions (Schaefer 2001). Male and female bluefin tuna sampled by purse seine around the Balearic Islands clearly had higher GSIs than those caught by longline. However, no remarkable histological differences were found between purse seine- and longline-caught males. Thus, the testis histological structure suggests that males in both samples were ready to spawn. Significantly higher GSIs in mature male bluefin tuna are thought to indicate larger stores of sperm in the central ducts of the testes (Abascal et al. 2004). Therefore, in longline-caught males, increased GSIs toward the second part of the fishing season suggest a higher sperm production and storage as the reproductive peak approaches.

In females the situation is somewhat different, since the mean GSI appears to remain invariable throughout the entire longline season. Results of the stereological analysis fit well into this data, since the numbers of vitellogenic oocytes and final-maturation oocytes, which are the oocyte classes that most significantly contribute to gonad weight (Abascal 2004), are similar in early and late longline catches. Lipid-stage oocytes, however, appear to become more scarce as the longline fishing season proceeds. This might reflect recruitment of lipid-stage oocytes into vitellogenic oocytes to compensate for losses caused by spawning and atresia, thereby maintaining a consistent pool of vitellogenic oocytes throughout the reproductive season. In support of this, the mean estimated number of yolked oocytes per $\mathrm{g}$ of $\mathrm{BW}$ remained quite constantbetween 282 and 285 oocytes $\mathrm{g}^{-1}$-irrespective of the time and method of capture.

Histological examination of ovaries revealed indisputable differences in reproductive condition between early and late longline catches and between both of these and purse-seine catches. For instance, while most females (ca. 96\%) sampled by purse seine were classified as AS, only ca. $25 \%$ of females in the early longline catches and $50 \%$ in the late longline catches exhibited histological features typical of AS fish. Similar percentages were observed for female tuna containing POFs in their ovaries, resulting in estimated spawning intervals of $4.4 \mathrm{~d}$ for bluefin tuna caught by 
longline during May through mid-June, 2 d for tuna caught by longline between mid-June and mid-July, and $1.2 \mathrm{~d}$ for those caught by purse seine between midJune and mid-July.

All the above observations show unequivocally that in the fishing ground studied, bluefin tuna targeted by purse seining show a higher proportion of reproductive activity on average than those caught by longlining. This is true even when comparing only the samples collected by the 2 gear types at the same period, and suggests that differences result basically from the particular nature of the gears themselves. The differences observed in proportions of reproductively active females between the purse seine and longline fisheries are apparently due to differences in behavior and thus vertical distributions of those individuals. Similarly, several authors have found substantially lower reproductive activity in yellowfin tuna caught by longline in comparison to those caught by purse seine in the same area and time (Suzuki et al. 1978, Koido \& Suzuki 1989, Bayliff 1994). Davis \& Farley (2001) showed that size partitioning by depth occurs in the spawning area of southern bluefin tuna Thunnus maccoyii. Vertical stratification by size is apparently related to spawning activity, such that spawning fish seem to be better represented in shallow catches than in deep catches, while nonspawning fish are better represented in deep catches than in shallow catches. It has been hypothesized that size partitioning with depth in this species is due to the fact that large fish spawn more often than smaller ones (Davis \& Farley 2001). These findings suggest that samples from the longline fishery are not suitable for estimating certain reproductive parameters, e.g. fecundity and spawning frequency.

The stereological concept has been applied to ovarian histological sections as an accurate tool for fecundity estimates in fishes (Coward \& Bromage 2002a). Stereometry is indeed a powerful procedure for quantifying oocytes in 3-dimensional samples. However, there is the problem that routine procedures commonly used in histology laboratories may cause significant shrinkage of the tissue samples. We calculated an average volume loss of $28 \%$ during histological processing, which should not be ignored when estimating numerical parameters by stereology. Earlier studies based on stereology (e.g. Medina et al. 2002) may have reported an overestimated fecundity (93 eggs $\mathrm{g}^{-1}$ ) in not having taken into consideration shrinkage associated with tissue treatment. Thus, the mean batch fecundity of 9 million eggs (82 eggs $\mathrm{g}^{-1}$ ) that is calculated directly from stereometric counts of finalmaturation oocytes in purse seine-caught spawners would drop to 6.5 million eggs, equivalent to a relative batch fecundity of 59 eggs $\mathrm{g}^{-1}$, after correction for volume reduction. This value is nearly identical to the relative batch fecundity calculated for southern bluefin tuna Thunnus maccoyii (57 eggs $\mathrm{g}^{-1}$; Farley \& Davis 1998) and is also close to the estimates reported for yellowfin tuna T. albacares (68 eggs $\mathrm{g}^{-1}$ in the eastern Pacific: Schaefer 1996; 55 eggs $\mathrm{g}^{-1}$ in the western Pacific and 64 eggs g ${ }^{-1}$ in Hawaii: Itano 2000). Somewhat lower values (24 eggs $\mathrm{g}^{-1}$ ) were obtained for bigeye tuna T. obesus by Schaefer et al. (2005).

Determining the spatiotemporal distribution of bluefin tuna populations is crucial for resource management. The International Commission for the Conservation of Atlantic Tunas (ICCAT) manages Atlantic bluefin tuna as 2 separate stock units. Although information provided by electronic tags does support the occurrence of 2 independent spawning populations, these appear to intermingle in the central Atlantic. A more recent view tends to reject the concept of a bluefin tuna stock consisting of geographically and reproductively isolated populations in favour of a metapopulation-like model (Fromentin \& Powers 2005). This supports the idea that bluefin tuna function as a set of discrete populations that experience a certain degree of demographic influence from other local populations. Within each local population, individuals would have migratory behaviours and use of common habitats. According to this paradigm, global research into bluefin tuna population dynamics would require comparative trans-oceanic surveys using the same sampling protocols (Fromentin \& Powers 2005). In particular, reproductive studies should carefully consider the type of gear used in sample collection, since the results obtained may be highly variable depending on the capture methods employed.

Bluefin tuna differ from other tuna species in having a reduced spatiotemporal window for reproduction (Schaefer 2001). In the western Mediterranean Sea, spawning takes place primarily in June/July, but the time individual fish take to complete the whole series of spawning events is so far unknown. Although breeding bluefin tuna are generally believed to reside for about 2 mo in areas of reproduction, archival data suggest that the effective time they spend on spawning grounds might actually be as short as $2 \mathrm{wk}$ (see Gunn \& Block 2001, p 212). This is in agreement with the finding that spent Thunnus maccoyii are seldom encountered on their spawning grounds, suggesting that they move south soon after spawning (Farley \& Davis 1998). Our results appear to indicate similar behaviour in T. thynnus, since the low proportions of inactive fish found in both longline and purse-seine catches suggest that bluefin tuna leave the spawning grounds shortly after having accomplished their reproductive function, thus becoming invulnerable to those fisheries. Considering the average spawning frequency of $0.85 \mathrm{~d}^{-1}$ estimated for reproductively 
active tuna, and the average batch fecundity of 6.5 million eggs, an average individual spawning duration of $14 \mathrm{~d}$ in the Balearic spawning ground would yield an average annual fecundity of around 77 million eggs per fish (relative annual fecundity of 702.1 eggs per $\mathrm{g}$ of BW). Indeed, an appropriate combination of reproductive biology studies coupled with data generated by the various electronic tagging programmes currently operating will help obtain a better understanding of the population dynamics of bluefin tuna. Further analysis of movement patterns around reproductive grounds should be encouraged in the near future with a view to improving the assessment of reproduction of Atlantic bluefin tuna stocks and building useful management models.

Acknowledgements. We gratefully acknowledge Nipon Mediterráneo, Tuna Graso and Mr. Ginés J. Méndez Alcalá for generously providing facilities and samples. The skilful technical assistance of Agustín Santos and Pilar Fernández is greatly appreciated. We are also indebted to the captains and crews of the fishing vessels 'Enrique el Gato', 'Joaquina Antonio', 'El Vitorino', 'Nicolás e Isabel' and 'Isleta Tercera'. This study has been funded by projects 1FD1997-0880-C05-04 (Spanish government), Q5RS-2002-01355 (European Union), and Red Eléctrica de España - Fundación Migres (Spain).

\section{LITERATURE CITED}

Abascal FJ (2004) Biología reproductiva del atún rojo atlántico, Thunnus thynnus (L.), en el Atlántico Oriental y el Mediterráneo. PhD thesis, University of Cádiz, Spain

Abascal FJ, Medina A (2005) Oogenesis ultrastructure in the bluefin tuna, Thunnus thynnus. J Morphol 264:149-160

Abascal FJ, Megina C, Medina A (2004) Testicular development in migrant and spawning bluefin tuna (Thunnus thynnus (L.)) from the eastern Atlantic and Mediterranean. Fish Bull 102:407-417

Baglin RE Jr. (1982) Reproductive biology of western Atlantic bluefin tuna. Fish Bull 80:121-134.

Bayliff WH (ed) (1994) Inter-American Tropical Tuna Commission, Annual Report for 1993. La Jolla, CA

Block BA, Dewar H, Blackwell SB, Williams TD and 7 others (2001) Migratory movements, depth preferences, and thermal biology of Atlantic bluefin tuna. Science 293: 1310-1314

Block BA, Teo SLH, Walli A, Boustany A and 5 others (2005) Electronic tagging and population structure of Atlantic bluefin tuna. Nature 434:1121-1127

Bromley PJ, Ravier C, Witthames PR (2000) The influence of feeding regime on sexual maturation, fecundity and atresia in first-time spawning turbot. J Fish Biol 56:264-278

Cooper DV, Pearson KE, Gunderson DR (2005) Fecundity of shortspine thornyhead (Sebastolobus alascanus) and longspine thornyhead (S. altivelis) (Scorpaenidae) from the northeastern Pacific Ocean, determined by stereological and gravimetric techniques. Fish Bull 103:15-22

Corriero A, Desantis S, Deflorio M, Acone F, Bridges CR, de la Serna JM, Megalofonou P, de Metrio G (2003) Histological investigation on the ovarian cycle of the bluefin tuna in the western and central Mediterranean. J Fish Biol 63: 108-119
Corriero A, Karakulak S, Santamaria N, Deflorio M and 11 others (2005) Size and age at sexual maturity of female bluefin tuna (Thunnus thynnus L. 1758) from the Mediterranean Sea. J Appl Ichthyol 21:483-486

Coward K, Bromage NR (1998) Histological classification of oocyte growth and the dynamics of ovarian recrudescence in Tilapia zillii. J Fish Biol 53:285-302

Coward K, Bromage NR (2001) Stereological validation of ovarian biopsy as a mean of investigating ovarian condition in broodstock tilapia in vivo. Aquaculture 195: 183-188

Coward K, Bromage NR (2002a) Quantification of ovarian condition in fish: a safer, more precise alternative to established methodology. Aquat Living Resour 15:259-261

Coward K, Bromage NR (2002b) Stereological point-counting; an accurate method for assessing ovarian function in tilapia. Aquaculture 212:383-401

Davis TLO, Farley JH (2001) Size distribution of southern bluefin tuna (Thunnus maccoyii) by depth on their spawning ground. Fish Bull 99:381-386

De Metrio G, Arnold GP, Block BA, de la Serna JM and 7 others (2002) Behaviour of post-spawning Atlantic bluefin tuna tagged with pop-up satellite tags in the Mediterranean and eastern Atlantic. Collect Vol Sci Pap ICCAT 54:415-424

De Metrio G, Oray I, Arnold GP, Lutcavage M and 5 others (2003) Joint Turkish-Italian research in the eastern Mediterranean: bluefin tuna tagging with pop-up satellite tags. Collect Vol Sci Pap ICCAT 56:1163-1167

Emerson LS, Greer Walker M, Witthames PR (1990) A stereological method for estimating fish fecundity. J Fish Biol 36: 721-730

Farley JH, Davis TLO (1998) Reproductive dynamics of southern bluefin tuna, Thunnus maccoyii. Fish Bull 96:223-236

Fromentin JM, Powers J (2005) Atlantic bluefin tuna: population dynamics, ecology, fisheries and management. Fish Fish 6:281-306

Greer Walker M, Witthames PR, Bautista de los Santos I (1994) Is the fecundity of the Atlantic mackerel (Scomber scombrus: Scombridae) determinate? Sarsia 79:13-26

Gunn J, Block B (2001) Advances in acoustic, archival, and satellite tagging of tunas. In: Block BA, Stevens ED (eds) Tuna: physiology, ecology and evolution. Academic Press, London, p 167-224

Gutiérrez M (1967) Coloración histológica para ovarios de peces, crustáceos y moluscos. Inv Pesq 31:265-271

Itano DG (2000) The reproductive biology of yellowfin tuna (Thunnus albacares ) in Hawaiian waters and the western tropical Pacific Ocean: project summary. Joint Institute for Marine and Atmospheric Research (JIMAR) Contribution 00-328. Pelagic Fisheries Research Program, University of Hawaii, JIMAR, Honolulu, HI

Karakulak S, Oray I, Corriero A, Deflorio M, Santamaria N, Desantis S, De Metrio G (2004) Evidence of a spawning area for the bluefin tuna (Thunnus thynnus L.) in the eastern Mediterranean. J Appl Ichthyol 20:318-320

Koido T, Suzuki Z (1989) Main spawning season of yellowfin tuna, Thunnus albacares, in the western tropical Pacific Ocean based on the gonad index. Bull Far Seas Fish Res Lab 26:153-163.

Lutcavage ME, Brill RW, Skomal GB, Chase BC, Howey PW (1999) Results of pop-up satellite tagging of spawning size class fish in the Gulf of Maine: Do North Atlantic bluefin tuna spawn in the mid-Atlantic? Can J Fish Aquat Sci 56: 173-177

Lutcavage ME, Brill RW, Goldstein JL, Skomal GB, Chase BC, Tutein J (2000) Tracking adult North Atlantic bluefin tuna 
(Thunnus thynnus) in the northwestern Atlantic using ultrasonic telemetry. Mar Biol 137:347-358

Medina A, Abascal FJ, Megina C, García A (2002) Stereological assessment of the reproductive status of female Atlantic northern bluefin tuna, Thunnus thynnus (L.), during migration to Mediterranean spawning grounds through the Strait of Gibraltar. J Fish Biol 60:203-217

Murua H, Kraus G, Saborido-Rey F, Witthames PR, Thorsen A, Junquera S (2003) Procedures to estimate fecundity of marine fish species in relation to their reproductive strategy. J Northw Atl Fish Sci 33:33-54

Oray I, Karakulak S (2005) Further evidence of spawning of bluefin tuna (Thunnus thynnus L., 1758) and the tuna species (Auxis rochei Ris., 1810, Euthynnus alletteratus Raf., 1810) in the eastern Mediterranean Sea: preliminary results of TUNALEV larval survey in 2004. J Appl Ichthyol 21:236-240

Schaefer KM (1996) Spawning time, frequency, and batch fecundity of yellowfin tuna, Thunnus albacares, near Clipperton Atoll in the eastern Pacific Ocean. Fish Bull 94:98-112

Schaefer KM (1998) Reproductive biology of yellowfin tuna (Thunnus albacares) in the eastern Pacific Ocean. InterAm Trop Tuna Comm Bull 21:201-272

Editorial responsibility: Kenneth Sherman (Contributing Editor), Narragansett, Rhode Island, USA
Schaefer KM (2001) Reproductive biology of tunas. In: Block BA, Stevens ED (eds) Tuna: physiology, ecology and evolution. Academic Press, London, p 225-270

Schaefer KM, Fuller DW, Miyabe N (2005) Reproductive biology of bigeye tuna (Thunnus obesus) in the eastern and central Pacific Ocean. Inter-Am Trop Tuna Comm Bull 23: $1-31$

Susca V, Corriero A, Bridges CR, de Metrio G (2001) Study of the sexual maturity of female bluefin tuna: purification and characterization of vitellogenin and its use in an enzymelinked immunosorbent assay. J Fish Biol 58:815-831

Suzuki Z, Tomlinson PK, Honma M (1978) Population structure of Pacific yellowfin tuna. Inter-Am Trop Tuna Comm Bull 17:273-441

Weibel ER, Gómez DM (1962) A principle for counting tissue structures on random sections. J Appl Physiol 17:343-348

Weibel ER, Kristler GS, Scherle WF (1966) Practical stereological methods for morphometric cytology. J Cell Biol 30: 23-38

Wilson SG, Lutcavage ME, Brill RW, Genovese MP, Cooper AB, Everly AW (2005) Movements of bluefin tuna (Thunnus thynnus) in the northwestern Atlantic Ocean recorded by pop-up satellite archival tags. Mar Biol 146:409-423

Submitted: May 18, 2006; Accepted: October 10, 2006 Proofs received from author(s): April 19, 2007 